\title{
ODPOWIEDZIALNOŚĆ W PRAWIE ATOMOWYM ZA SZKODĘ JĄDROWĄ W ŚRODOWISKU
}

\section{LIABILITY IN NUCLEAR LAW FOR NUCLEAR DAMAGE IN ENVIRONMENT}

\section{STRESZCZENIE}

Celem artykułu było przedstawienie odpowiedzialności za szkodę jądrową w środowisku. Wykazano, że szkoda jądrowa w środowisku nie jest czystą szkodą ekologiczną. Jest to rodzaj szkody w mieniu. Artykuł ukazuje obowiązujący stan prawny prawa atomowego w Polsce. $\mathrm{W}$ pracy przedstawiono także uwagi krytyczne i wysunięto postulaty de lege ferenda.

\section{Słowa kluczowe}

Prawo atomowe, odpowiedzialność, wyjątek, wykładnia prawa, stan prawny.

Aplikantka adwokacka, doktorantka w Katedrze Prawa Gospodarczego Publicznego i Ochrony Środowiska WPiA UG. 


\begin{abstract}
The purpose of this article is to present the issue of liability in nuclear law for nuclear damage in environment. The nuclear damage in environment is not a typical environmental loss but rather it is a kind of economic loss. This paper presents legal status in nuclear law in Poland. Author presents also critical comments and proposes de lege ferenda postulates.

\section{Keywords}

Nuclear law, liability, exception, interpretation of law, legal status.
\end{abstract}

Energetyka jądrowa to wciąż bardzo młoda gałąź nauki i techniki. Jej rozwój przynosi światu ogromne korzyści, ale niesie też ze sobą wielkie zagrożenia. Hiroszima, Nagasaki są jak hasła, które trwale zapisały się w tragicznej historii ludzkości. Tamtejsze promieniowanie jonizujące, ogrom zniszczeń, ranni i zabici, zniszczone całkowicie obiekty budowlane i ujawniające się po latach choroby i powikłania popromienne sprawiły, że społeczność międzynarodowa zrozumiała, że ryzyko jakie niesie ze sobą rozwój energetyki jądrowej jest większe niż ktokolwiek mógłby przypuszczać. Pokojowe wykorzystanie energii jądrowej od tamtej pory stało się priorytetem. Jednak to dopiero awaria w Czarnobylu uświadomiła, że także pokojowe wykorzystanie urządzeń jądrowych stać się może źródłem nieprzewidzianych do końca i niekontrolowanych zagrożeń dla człowieka i środowiska. Katastrofa u naszych sąsiadów uwidoczniła coś jeszcze, niemoc wobec osób odpowiedzialnych za to zdarzenie, a tym samym brak jakichkolwiek środków prawnych, które pozwalałaby na uzyskanie przez poszkodowanych godnego, prawego i sprawiedliwego wynagrodzenia szkód.

Odpowiedzialność w prawie atomowym to kluczowe zagadnienie. Reżim tej odpowiedzialności nie jest w pełni dojrzały czy ustalony. Podlega on ciągłemu rozwojowi z uwagi na pojawiające się zagrożenia oraz osiągnięcia nauki. Jeszcze tak niedawno nikt nie spodziewałby się ataków terrorystycznych na 
obiekty jądrowe, dziś takie zagrożenie jest jak najbardziej realne. Prawo atomowe (zwane także w doktrynie nuklearnym) nadal się kształtuje, jednak pod uwagę należy brać fakt, iż pierwowzory wszystkich międzynarodowych uregulowań powstawały w okresie największych napięć politycznych na świecie. Nie tak łatwo było skłonić największe mocarstwa do kompromisu i ujednolicenia reguł nuklearnej gry. Do dziś dostrzec można tego pozostałości. Państwa wykorzystujące energię atomową na wielką skalę $\mathrm{w}$ przemyśle energetycznym próbują złagodzić odpowiedzialność atomową, a te korzystające z urządzeń atomowych w niewielkim zakresie np. w celach badawczych czy medycznych są bardzo restrykcyjne w sprawie odpowiedzialności atomowej.

Wydaje się oczywistym, że nie da się stworzyć systemu ochrony przed szkodami powstałymi w wyniku działań zbrojnych. W grę wchodzić może wtedy jedynie tzw. odpowiedzialność polityczna oraz odpowiedzialność poszczególnych państw wobec obywateli na zasadach ogólnych, jeśli w toku działań militarnych doszłoby do wyrządzenia szkody ${ }^{1}$. Trudna bowiem do wytłumaczenia byłaby sytuacja, w której to szkoda jądrowa spowodowana akcją wojskową wroga miała być pokrywana przez eksploatującego obiekt jądrowy. W takich sytuacjach głównie to on ponosi szkodę, ponieważ z reguły akcja wojskowa łączy się z uszkodzeniem instalacji, którą eksploatuje² .

Można jednak stworzyć system ochrony człowieka, jego dóbr materialnych i środowiska naturalnego, by jego poczucie bezpieczeństwa rosło, pokojowe wykorzystanie energii atomowej dalej się rozwijało, a państwa współtworzące ten system nie bały się go stosować. Tym o to sposobem doszło do wypracowania tzw. międzynarodowego prawa atomowego. $\mathrm{W}$ tak szeroko pojętym międzynarodowym prawie atomowym wyróżniamy dwa systemy międzynarodowego prawa odpowiedzialności cywilnej za szkodę jądrową. Jest to system Organizacji Narodów Zjednoczonych, zwanym $\mathrm{w}$ literaturze systemem wiedeńskim

1 R. Majda, Cywilna odpowiedzialność za szkodę jądrowq w polskim prawie atomowym, Łódź 2006, s. 18.

2 B. Lewaszkiewicz-Petrykowska, Cywilna odpowiedzialność za szkodę jqdrowq w polskim prawie atomowym, „Państwo i Prawo” 1987, nr 4, s. 34. 
(od miejsca podpisania konwencji ${ }^{3}$ i siedziby Międzynarodowej Agencji Energii Atomowej) oraz system Organizacji Współpracy Gospodarczej i Rozwoju, zwanym systemem paryskim (od miejsca podpisania Konwencji o odpowiedzialności cywilnej w dziedzinie energii jądrowej i od siedziby OECD). Oba systemy i ich zasadnicze konwencje były kilkakrotnie zmieniane, aż do awarii w Czarnobylu także konkurowały ze sobą. Dopiero 21 września 1988 r. podpisano protokół odnoszący się do zastosowania konwencji paryskiej i wiedeńskiej ${ }^{4}$.

Podstawowe znaczenie dla odpowiedzialności za szkodę jądrową ma właściwe zdefiniowanie zdarzenia, z którym wiązać będziemy tą odpowiedzialność. Polska ustawa z 29 listopada 2000 r. Prawo atomowe ${ }^{5}$ w art. 100 pkt. 8 definiuje wypadek jądrowy jako jakiekolwiek zdarzenie lub serię zdarzeń mających to samo źródło pochodzenia, które powodują szkodę jądrową lub poważne i bezpośrednie zagrożenie jej powstania. Rozwiązanie takie jest wzorowane na konwencji wiedeńskiej i protokole zmieniającym ją. Wystąpienie wypadku jądrowego może być całkowicie niezależne od aktywności człowieka, może też mieć swe źródło w jego zachowaniu (działaniu lub zaniechaniu). Najogólniej mówiąc, szkodą jądrową jest każdy uszczerbek, który został spowodowany na skutek wypadku jądrowego. Wypadki takie mogą przybierać postać czystego zdarzenia jądrowego (wypadki radiacyjne), w których szkodliwość polega na skażeniu i oddziaływaniu promieniowania albo są to wypadki, którym towarzyszą zjawiska pożaru, eksplozji (tzw. mieszana postać szkody jądrowej) ${ }^{6}$. W każdym z tych wypadków wystąpi szkoda jądrowa. Ustawodawca definiując szkodę jądrową posłużył się wymienieniem jej charakterystycznych postaci i cech. Nie wprowadził jed-

3 Konwencja wiedeńska o odpowiedzialności cywilnej za szkodę jądrową, sporządzona w Wiedniu dnia 21 maja 1963 r., Dz. U. z 1990 r. Nr 63, poz. 370 ze zm.

4 Wspólny protokół dotyczący stosowania Konwencji wiedeńskiej i Konwencji paryskiej (o odpowiedzialności za szkody jądrowe) sporządzony w Wiedniu dnia 21 września 1988 r., Dz. U. z 1994 r. Nr 129, poz. 633.

5 T.j. Dz. U. 2007 r. Nr 42, poz. 276 ze zm., dalej cyt.: ustawa Prawo atomowe.

6 R. Majda, Cywilna odpowiedzialność..., s. 52.

PRIEELAD PRAWA OCHRONY ŚRODOWIIKHA 
nak autonomicznej definicji szkody jądrowej, a jedynie uściślił jej specyfikę, wyróżniając pewne jej elementy.

Szkodę jądrową można podzielić zgodnie z ustawą Prawo atomowe na szkodę na osobie, szkodę w mieniu, szkodę w środowisku jako dobru wspólnym (chodzi tu o koszty zastosowanych środków mających na celu przywrócenie stanu środowiska, jako dobra wspólnego, sprzed jego naruszenia, chyba że naruszenie jest nieznaczne) - w zakresie, w jakim szkoda powstała lub wynika z promieniowania jonizującego emitowanego przez jakiekolwiek źródło promieniowania wewnątrz urządzenia jądrowego lub emitowanego przez paliwo jądrowe, materiały promieniotwórcze, odpady lub materiał jądrowy, pochodzące $\mathrm{z}$ urządzenia jądrowego, powstałe w nim lub wprowadzone do niego, jeżeli wynikają one $\mathrm{z}$ właściwości promieniotwórczych tej substancji lub z połączenia właściwości promieniotwórczych z trującymi, wybuchowymi lub innymi niebezpiecznymi właściwościami takiej substancji.

Wyróżnienie szkody w środowisku jako jednego z typów szkody jądrowej jest wyrazem międzynarodowego trendu ochrony środowiska. Istotny rozwój prawnej ochrony środowiska zaczął się pod koniec XX wieku. Przez długie lata międzynarodowe prawo atomowe nie znało indemnizacji tej postaci szkody. Jedyną próbą ochrony środowiska była podpisana w $1971 \mathrm{r}$. konwencja o odpowiedzialności cywilnej za szkodę powstałą w czasie transportu materiałów nuklearnych. Przewidywała ona odszkodowanie za zanieczyszczenie morza. Niestety, nie została wprowadzona w życie. Dopiero w 1993 r. po awarii w Czarnobylu i długich dyskusjach na arenie międzynarodowej została podpisana w Lugano konwencja o odpowiedzialności cywilnej za szkody wyrządzone działalnością niebezpieczną dla środowiska. Konwencja ta wprowadziła pojęcie środowiska i szkody w środowisku i była wzorcem dla protokołu zmieniającego konwencję wiedeńską podpisaną w $1997 \mathrm{r}$. W Protokole tym została wprowadzona odrębna postać szkody jądrowej tj. szkoda w środowisku.

Pierwsza polska ustawa regulująca prawo atomowe została uchwalona 10 kwietnia 1986 r. ${ }^{7}$ Była uznawana za dojrzały i do-

7 Ustawa z dnia 10 kwietnia 1986 r. Prawo atomowe, Dz. U. z 1986 r. Nr 12, poz. 70 . 
bry akt prawny również poza granicami naszego kraju, głownie dzięki wyodrębnieniu szkody w środowisku. Jednakże wydarzenia w Czarnobylu, zaledwie dwa tygodnie po uchwaleniu polskiej ustawy Prawo atomowe, stały się przyczyną do rewizji poglądów i rozwiązań prawnych $\mathrm{w}$ obrębie regulacji poświęconych prawu atomowemu. Ustawodawca regulując zakres szkody wprowadził obowiązek wyrównania uszczuplenia dobra wspólnego wskutek uszkodzenia środowiska. Roszczenie odszkodowawcze przysługiwało Skarbowi Państwa, a samo odszkodowanie stanowiło dochód Funduszu Ochrony Środowiska.

Obecnie polski ustawodawca stanowi o szkodzie w środowisku jako dobru wspólnym. Definicja legalna „środowiska” $\mathrm{W}$ polskim systemie prawnym znajduje się $\mathrm{w}$ ustawie $\mathrm{z}$ dnia 27 kwietnia 2001 r. Prawo ochrony środowiska ${ }^{8}$. Środowisko to ogół elementów przyrodniczych, w tym także przekształconych w wyniku działalności człowieka, a w szczególności powierzchnia ziemi, kopaliny, wody, powietrze, krajobraz, klimat oraz pozostałe elementy różnorodności biologicznej, a także wzajemne oddziaływania pomiędzy tymi elementami. Szkoda w środowisku polegać będzie na uszczerbku w wymienionych dobrach. Sformułowanie „dobro wspólne” oznacza te elementy środowiska, które służą całemu społeczeństwu. Doktryna utożsamia dobro wspólne z kategorią znaną w prawie rzymskim jako res omnium communes.

Odwołując się do powyższej definicji, można sformułować ogólną tezę, iż szkoda w środowisku polegać będzie na uszczerbku w wymienionych dobrach, a także na tzw. zachwianiu równowagi naturalnej. Przez zachwianie równowagi rozumieć głównie należy zakłócenie związków pomiędzy elementami przyrodniczymi. W tym miejscu warto się zastanowić czym są elementy środowiska. Czy są to rzeczy, składniki mienia a może dobra niematerialne. Wbrew pozorom to istotne pytanie dla dalszych rozważań. Odpowiedź na nie jest niejednoznaczna. Przykładem

8 T.j. Dz. U. z 2008 r. Nr 25 poz. 150 ze zm., art. 3 pkt. 39; dalej cyt.: ustawa Prawo ochrony środowiska. 
może być choćby las, który stanowić może własność określonej osoby ale jest też rozumiany jako element środowiska9

Wysokość odszkodowania za szkodę w środowisku jest ograniczona do wysokości kosztów restytucji środowiska oraz równowartości utraconych $\mathrm{w}$ ten sposób korzyści. Naprawienie szkody jądrowej obejmuje także zwrot kosztów środków zapobiegawczych. Eksploatujący nie ponosi odpowiedzialności, gdy szkoda jest nieznaczna. Ustawodawca stawia także warunek, by środki przywracające stan środowiska sprzed jego naruszenia były zastosowane przez właściwe organy lub na podstawie ich decyzji przez inne podmioty ${ }^{10}$. Odszkodowanie obejmuje zatem koszty odtworzenia stanu środowiska. Szkoda ma więc charakter majątkowy w postaci konieczności poniesienia wydatków.

Roszczenie o naprawienie szkody jądrowej w środowisku przedawnia się z upływem trzech lat od dnia, w którym poszkodowany dowiedział się lub powinien był się dowiedzieć o szkodzie i osobie odpowiedzialnej. Jednakże roszczenie wygasa $\mathrm{z}$ upływem dziesięciu lat od dnia wypadku jądrowego. Ustawodawca wprowadził obowiązek zawarcia umowy ubezpieczenia odpowiedzialności cywilnej za szkody jądrowe. Oczywistym jest w tego typu sprawach, że roszczenie o odszkodowanie z tytułu szkody jądrowej może być dochodzone bezpośrednio od zakładu ubezpieczeń. Granicą odpowiedzialności osoby eksploatującej za szkodę jądrową jest kwota stanowiąca po najnowszej zmianie ustawy ${ }^{11}$ równowartość $300 \mathrm{mln}$ SDR (jednostek rozrachunkowych Międzynarodowego Funduszu Walutowego).

Artykuł 100 pkt 5 ustawy Prawo atomowe nie wprowadza, jakby się mogło wydawać, szkody ekologicznej w czystej postaci (pure economic loss). Redakcja punktu 5 tego artykułu wskazuje co prawda, że jest to autonomiczna postać szkody to jednak po wczytaniu się w cały art. 100 pkt 5, można dojść do przekonania, że jest to szczególna postać szkody w mieniu. Szkoda w środowi-

9 Patrz szerzej, J. J. Skoczylas, Odpowiedzialność cywilna na podstawie ustawy - prawo ochrony środowiska, „Przegląd Sądowy” 2003, nr 4, s. 65.

10 R. Majda, Cywilna odpowiedzialność..., s. 105

11 Ustawa z dnia 13 maja 2011 r. o zmianie ustawy - Prawo atomowe oraz niektórych innych ustaw, Dz. U. z 2011 r. Nr. 132, poz. 766. 
sku polegać bowiem ma na poniesieniu wydatków w celu przywrócenia stanu środowiska sprzed naruszenia. Także określenie środowiska jako dobra wspólnego nie zmienia faktu, że nie mamy do czynienia ze szkodą ekologiczną. W każdym przypadku szkody w środowisku chodzić będzie o uszczerbek majątkowy w dobrach osoby, która podjęła stosowne działania zmierzające do restytucji skażonych elementów środowiska albo o nieosiągnięcie korzyści w związku z przeznaczeniem dostępnych poszkodowanemu środków na tę restytucję. Szkoda w środowisku nie obejmuje swym zakresem ujemnych społecznych ani indywidualnych skutków degradacji środowiska naturalnego ${ }^{12}$.

Rodzi się jednak pytanie po co racjonalny ustawodawca w art. 105 ust. 3 ustawy Prawo atomowe stwierdził, że roszczenie o naprawienie szkody w środowisku przysługuje ministrowi właściwemu do spraw ochrony środowiska. Czy chodzi w tym wypadku tylko i wyłącznie o sytuacje, w których to Skarb Państwa jest poszkodowanym? Nie wydaje się by taki był cel ustawodawcy.

Zgodnie z art. 100a ustawy Prawo atomowe, naprawienie szkody jądrowej następuje na zasadach określonych w przepisach k.c. ${ }^{13}$, z zastrzeżeniem wyjątków przewidzianych w ustawie. Ponadto art. 107 ust. 2 tejże ustawy stanowi, że w sprawach odszkodowań, w zakresie nieregulowanym w rozdziale 12 ustawy zatytułowanym odpowiedzialność cywilna za szkody jądrowe, stosuje się także przepisy k.c. W konsekwencji oznacza to, że cywilna odpowiedzialność za tzw. szkody jądrowe musi być analizowana przy łącznym uwzględnieniu norm prawa atomowego oraz przepisów k.c.

Wracając w tym miejscu do przykładu lasu, można powiedzieć, że jego właścicielowi w przypadku wypadku jądrowego przysługiwałoby odszkodowanie za szkodę jądrową (szkodę w mieniu). Właściciel ten jednak może zwrócić się do państwa o pomoc w celu np. rekultywacji terenu. Państwo obowiązane do

12 R. Majda, Cywilna odpowiedzialność za szkodę jądrowq w nowym prawie atomowym, „Przegląd Sądowy” 2002, nr 6, s. 53-54.

13 Ustawa z dnia 23 kwietnia 1964 r. Kodeks Cywilny, Dz. U. z 1964 r. Nr 16, poz. 93 ze zm., dalej cyt.: k.c. 
dbałości o środowisku zostanie zmuszone do działania dla dobra wspólnego. W takim wypadku to państwo będzie uprawnione do dochodzenia roszczeń za szkodę w środowisku naturalnym ${ }^{14}$.

Układając powyższe wywody w jedną spójną całość uznać należy, że co prawda szkoda w środowisku nie jest szkodą ekologiczną w czystej postaci (notabene do końca nie jest wiadome, czym jest czysta szkoda ekologiczna), jest jednak autonomicznym rodzajem szkody jądrowej o cechach jak najbardziej majątkowych. Można zatem w skrócie powiedzieć, że szkoda w środowisku jest szczególnym rodzajem szkody w mieniu.

Z przepisów o odpowiedzialności cywilnej za szkodę jądrową wynika, że wyłączną odpowiedzialność za szkodę jądrową, czyli szkodę na osobie w mieniu czy w środowisku, spowodowaną promieniotwórczym, toksycznym, wybuchowym lub innym działaniem materiału jądrowego i jego produktów rozszczepienia, ponosi osoba eksploatująca obiekty jądrowe. W przypadku, gdy więcej niż jedna osoba eksploatowałaby taki obiekt, ich odpowiedzialność musi być uznana za solidarna ${ }^{15}$. Przez „osobę eksploatującą" rozumie się podmiot eksploatujący urządzenie jądrowe.

Rozdział 12 ustawy Prawo atomowe wprowadza także odpowiedzialność cywilną za szkodę powstałą podczas przewozu przesyłki. Ustawodawca stanowi, że w czasie transportu materiałów jądrowych odpowiedzialność ponosi osoba eksploatująca urządzenie jądrowe, z którego ten materiał został wysłany, chyba, że umowa z odbiorcą stanowi inaczej. Oznacza to, że odpowiedzialność wobec osób trzecich ponosi osoba eksploatująca, która nadała przesyłkę, aż do chwili wydania takiej przesyłki odbiorcy. W przypadku transportu materiału jądrowego z urządzenia jądrowego, osoba eksploatująca obowiązana jest dodatkowo do zawarcia umowy ubezpieczenia za szkodę jądrową wyrządzoną w czasie transportu. Obowiązek taki powstaje nie później niż w dniu poprzedzającym dzień rozpoczęcia transportu materiału

14 R. Majda, Cywilna odpowiedzialność za szkodę jądrowq w polskim prawie atomowym, s. 112-113.

15 P. Sobieszewski, Polskie Prawo Atomowe, [w:] J. Szreniewski (red.), Prawo administracyjne część szczegótowa, Toruń 2001, s. 313. 
jądrowego z urządzenia jądrowego. Innym zagadnieniem jest czy takie uregulowania są wystarczające i czy chronią odpowiednio ewentualnych przyszłych poszkodowanych.

Należy też zaznaczyć, że ustawa przewiduje w pewnych ściśle wyjątkowych sytuacjach wyłączenie odpowiedzialność eksploatującego obiekt. Jest tak, jeżeli szkoda jądrowa wynikła z działań wojennych lub konfliktu zbrojnego albo z wyłącznej winy umyślnej poszkodowanego. Wynika z powyższego, że okoliczności zwalniające od odpowiedzialności za szkody atomowe nie wyczerpują pojęcia tzw. siły wyższej (vis maior, Act of God), która z reguły zwalnia od odpowiedzialności opartej na zasadzie ryzyka. Tylko niektóre przypadki siły wyższej zachowały moc egzonerującą. Wyrządzenie szkody z winy osób trzecich także nie zwalania z odpowiedzialności podobnie jak wina nieumyślna samego poszkodowanego. Odpowiedzialność osób wykorzystujących energię atomową zbliżona jest zatem do granicy tzw. odpowiedzialności absolutnej ${ }^{16}$.

Zakres okoliczności egzoneracyjnych od początku istnienia polskiego prawa atomowego był bardzo podobny. Różnice tkwiły co najwyżej w redakcji stosowanych postanowień ustawy. W doktrynie wciąż nie zdecydowano się, czy w odpowiedzialności za szkodę jądrową mamy do czynienia z odpowiedzialnością obiektywną czy absolutną. Większość przedstawicieli doktryny skłania się do klasyfikowania tej odpowiedzialności jako obiektywnej (niezależnej od winy) zbliżonej do absolutnej. Jest to dobrym rozwiązaniem, bowiem odpowiedzialność absolutna wydaje się za wąska, a odpowiedzialność obiektywna zbyt szeroka. Być może warto jednak na chwile pochylić się nad konstrukcją znaną od lat w doktrynie jako odpowiedzialność nieomal absolutną. Takie rozważania czysto teoretyczne w praktyce okazać mogą się kiedyś kluczowe przy sądowym dochodzeniu roszczeń za szkodę jądrową.

Ustawa prawo atomowe w żaden sposób nie odnosi się do związku przyczynowego pomiędzy zderzeniem (wypadkiem) jądrowym, a szkodą jądrową. Dlatego też dla jego ustalenia stoso-

16 J. Rajski, Odpowiedzialność międzynarodowa za szkody wyrządzone przez obiekty kosmiczne, Warszawa 1974, s. 89. 
wać należy reguły ogólne. Przy szkodzie w środowisku, poszkodowany będzie musiał wykazywać za pomocą opinii biegłych, że np. stan zagrożenia wywołany wypadkiem jądrowym uzasadniał podjęcie określonych działań zapobiegawczych. Trudności sprawić może dystans czasowy między ujawnieniem się szkody a wywołującym ją zdarzeniem. Z wykazaniem normalnego związku przyczynowego nie powinno być większych trudności, bowiem promieniowanie jonizujące może spowodować nieskończenie długą listę szkód. Należy się zastanowić, czy obowiązujący stan prawny w interesującej nas kwestii jest zadawalający. W chwili obecnej prawo atomowe jest nadal w fazie rozwoju. Powoduje to, że prawo atomowe jest niezwykle drażliwe i wrażliwe na nowinki technologiczne związane z energetyką jądrową i powstającymi nowymi rozwiązaniami. Nadal w pełni nie jest ukształtowane pojęcie szkody jądrowej. Występują rozbieżności w prawie wewnętrznym stron - członków konwencji. Brak bogatego orzecznictwa w tym zakresie, co paradoksalnie jest oczywiście pozytywne. Wydaje się jednak, że charakter odpowiedzialności za szkodę jądrową nie ulegnie już zmianie.

Jako postulat de lege ferenda warto wspomnieć o braku przesłanki wyłączającej odpowiedzialność za szkodę jądrową w wypadku ataku terrorystycznego. Ustawodawca nie przewidział takiej okoliczności wprost w ostatniej nowelizacji. Trudno także mówić by atak terrorystyczny był przejawem działań wojennych czy konfliktu zbrojnego. Taka rozszerzająca interpretacja budziłaby wątpliwości. Szkoda, że ustawodawca nie pomyślał o tym w dobie globalnej wojny z terroryzmem. Atak na elektrownię jądrową mógłby przynieść ogromne straty w środowisku, a przecież polski program energetyki jądrowej zakłada budowę pierwszego bloku elektrowni jądrowej do 2020 r. Miejmy nadzieję, że do tego czasu uda się stworzyć wysoki standard ochrony poszkodowanych i stworzyć właściwe warunki dla ochrony środowiska. Szkoda jądrowa pod postacią szkody w środowisku jest na obecny stan prawny traktowana dość po macoszemu i należałoby to zmienić przed budową w Polsce elektrowni jądrowej.

Prawdopodobnie do istniejących już 400 działających na świecie reaktorów jądrowych dołączą kolejne (nie tylko polski), bowiem Unia Europejska postawiła sobie za cel ogranicze- 
nie emisji dwutlenku węgla do atmosfery (energetyka jądrowa uznawana jest za bezemisyjne źródło energii) Czy to oznacza, że Europa (jak twierdzą niektórzy komentatorzy) wyjdzie z traumy Czarnobyla? Czas pokaże, w dużej mierze będzie to zależeć od rozwiązań prawnych i odpowiedniego zabezpieczenia na wypadek szkody jądrowej. Nie zapominajmy, że nadal trwa dramat elektrowni japońskich. Dopóki nie poznamy prawdziwych rozmiarów tamtejszych szkód, problemów technicznych, bezpośrednich i pośrednich konsekwencji trudno powiedzieć czy istniejące rozwiązania prawne $\mathrm{w}$ obrębie międzynarodowego prawa atomowego i rodzimego są wystarczające dla ochrony środowiska.

\section{BIBLIOGRAFIA}

Lewaszkiewicz-Petrykowska B., Cywilna odpowiedzialność za szkodę jqdrowq w polskim prawie atomowym, „Państwo i Prawo” 1987, nr 4.

Majda R., Cywilna odpowiedzialność za szkodę jądrowq w nowym prawie atomowym, „Przegląd Sądowy” 2002, nr 6.

Majda R., Cywilna odpowiedzialność za szkodęjądrowq w polskim prawie atomowym, Łódź 2006.

Rajski J., Odpowiedzialność międzynarodowa za szkody wyrządzone przez obiekty kosmiczne, Warszawa 1974.

Skoczylas J. J., Odpowiedzialność cywilna na podstawie ustawy - prawo ochrony środowiska, „Przegląd Sądowy” 2003, nr 4.

Sobieszewski P., Polskie Prawo Atomowe, [w:] J. Szreniewski (red.), Prawo administracyjne część szczegótowa, Toruń 2001.

Kontakt e-mail:

natalia.tucholska@wp.pl 